\title{
Carcinomas and carcinoid tumours of the appendix in a district general hospital
}

\author{
R. A. JONES AND A. MACFARLANE \\ From Nottingham University Department of Pathology and King's Mill Hospital, Sutton-in-Ashfield
}

SYNOPSIS In a retrospective series of 40 appendiceal tumours occurring over a 10 -year period, 30 were carcinoid tumours of classical histological pattern, five were adenocarcinomas, and two were tumours intermediate in pattern between carcinoid and carcinoma. The remaining three tumours were secondaries from primary colonic tumours. The implications of the findings are discussed.

Primary epithelial tumours of the appendix are relatively uncommon, and adenocarcinoma arising in the appendix is generally regarded as a lesion of considerable rarity. The true incidence of carcinoma is difficult to estimate owing to confusion with argentaffin carcinoid tumours, reactive epithelial conditions following episodes of obstruction, and secondary spread from primary tumours of the gastrointestinal tract and other organs (Latchis and Canter, 1966). Recent publications (Klein, 1974; Subbuswamy et al, 1974) have described forms intermediate between carcinoid and carcinoma. The present study was carried out to assess the relative frequency and clinical importance of such tumours in a district general hospital.

\section{Material and methods}

Material was taken from the surgical pathology files of King's Mill Hospital, Sutton-in-Ashfield. The laboratory serves a population of approximately 250000 . During the 10-year period 1965-75 the total number of appendicectomy specimens examined histologically was 4107 . Appendices were routinely received unopened from the operating theatres and were examined macroscopically by making several transverse sections through the base and middle of the appendix and a longitudinal section through the tip. In each appendix, one half of the longitudinal tip section and two or more of the transverse sections were embedded and examined histologically. Sections were stained routinely with haematoxylin and eosin; those containing tumour were stained with diazo method for enterochromaffin granules and the periodic acid Schiff method. Selected sections

Received for publication 7 January 1976 were also stained with alcian blue, the buffered silver nitrate method of Grimelius (1968), the lead haematoxylin technique (Solcia et al, 1969), and Singh's technique for argentaffin granules (Singh, 1964).

\section{Results}

Forty of the 4107 appendices contained tumour. The tumours fell into four catagories:

(A) Thirty $(0.75 \%$ of appendices examined) were carcinoid tumours of classical pattern, consisting of infiltrating cords and rosettes of cells, the majority of which stained positively with diazo, argentaffin or argyrophil techniques (fig 1). In 14 of these cases, the tumour cells formed occasional acini containing PAS positive mucin. Table I shows the clinical and pathological features of these tumours, and table II shows their staining reactions.

The mode of presentation of the classical carcinoid tumours was variable. Tumours in the middle third and base of the appendix predominated among the 19 cases presenting with symptoms of a classical attack of acute appendicitis. Fifteen of these cases showed acute inflammation on histological examination. There was no correlation between the size and site of the tumours and none of the cases showed any systemic or remote gastrointestinal symptoms indicative of a carcinoid syndrome.

(B) Two tumours $(0.05 \%)$ resembled carcinoids in their histological pattern but contained mucinsecreting cells in numbers that equalled or exceeded those of the argentaffin and argyrophil cells (fig 2). Table III gives the clinical and pathological details of these cases.

(C) Five tumours $(0 \cdot 12 \%)$ were adenocarcinomas forming tubules or cystic structures containing mucin (figs 3 and 4). One tumour contained small 


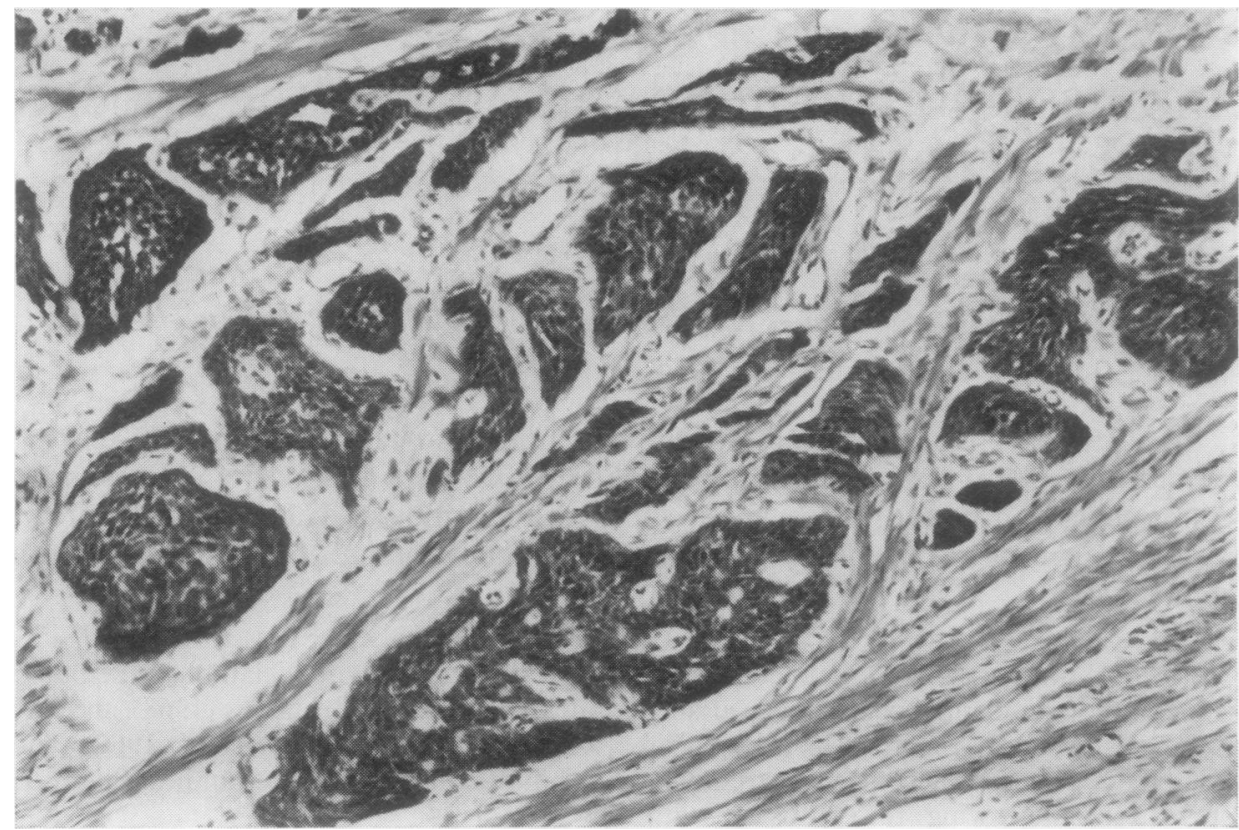

Fig 1 A diazo positive carcinoid of classical pattern forming interlacing cords and masses in the lamina propria. (Haematoxylin and eosin $\times 120)$

\begin{tabular}{|c|c|c|c|c|c|c|c|}
\hline \multirow[t]{2}{*}{ Presentation } & \multirow{2}{*}{$\begin{array}{l}\text { Total } \\
\text { number }\end{array}$} & \multicolumn{3}{|c|}{ Site of tumour } & \multicolumn{3}{|c|}{ Size of tumour $(\mathrm{cm})$} \\
\hline & & Tip & $\begin{array}{l}\text { Middle } \\
\text { third }\end{array}$ & Base & 0.5 & $0 \cdot 5-1$ & $1-2$ \\
\hline Surgical diagnosis of acute appendicitis & 19 & 5 & 11 & 3 & 5 & 9 & 5 \\
\hline Removed for recurrent abdominal pain & 4 & 3 & 1 & 0 & 2 & 1 & 1 \\
\hline Incidental removal at laparotomy for other reasons & $7^{1}$ & 6 & $\mathbf{0}$ & $\mathbf{0}$ & 5 & $\mathbf{0}$ & 2 \\
\hline
\end{tabular}

Table I Presenting features and macroscopic pathology of carcinoid tumours of classical pattern 'One removed incidentally at cholecystectomy involved the whole length of the appendix

\begin{tabular}{llll}
\hline PAS & $\begin{array}{l}\text { Argentaffin } \\
\text { and diazo } \\
\text { positive }\end{array}$ & $\begin{array}{l}\text { Argyrophil } \\
\text { positive } \\
\text { argentaffin negative }\end{array}$ & $\begin{array}{l}\text { Argentaffin and } \\
\text { argyrophil negative }\end{array}$ \\
\hline $\begin{array}{lll}\text { Positive } \\
\text { Negative }\end{array}$ & 12 & 2 & 0 \\
\hline
\end{tabular}

Table II Staining reactions of carcinoid tumours of classical pattern

numbers of diazo positive cells as an integral part of the tumour. The primary appendiceal origin of these tumours was established either at necropsy or by laparotomy and colectomy. Table IV gives clinical and pathological details.

(D) Three other adenocarcinomas were shown to be secondary carcinomas from primary tumours in the colon. Two were instances of transcoelomic spread; one was direct spread from a caecal carci- $\circ$ noma which was not obvious at appendicectomy. All showed acute inflammation of the appendix.

\section{Discussion}

The overall incidence of carcinoid tumours in this $\mathrm{N}_{\mathrm{W}}$ series is $0.75 \%$. This figure is comparable to that of Collins (1963), who found an incidence of $0.689 \%$ Dische (1968) reported an incidence of $1.3 \%$ in $a \frac{\bar{\Phi}}{2}$ series of 1426 appendices in which both halves of the $\stackrel{\text { ? }}{+}$ longitudinally divided terminal $1.5 \mathrm{~cm}$ were embed- $T$ ded and sectioned; more proximal areas were ${ }_{\bar{P}}$ sectioned only where there was a definite indication $\stackrel{\odot}{\circ}$ to do so. We have embedded and sectioned only one $\stackrel{\vec{Q}}{\square}$ half of the tip but have routinely embedded trans- $\frac{}{\sigma}$ verse sections from more proximal areas. The $48 \%$ 


\begin{tabular}{|c|c|c|c|c|}
\hline Case & Presentation & Pathology & Operation & Follow-up \\
\hline $\begin{array}{l}\text { Female } \\
60 \mathrm{yr}\end{array}$ & Acute abdominal pain & $\begin{array}{l}\text { Tumour invading submucosa of appendix for } 1.5 \mathrm{~cm} \\
\text { near the tip. Diazo positive cords, numerous acini } \\
\text { with pools of mucin (fig 2), and Paneth cells in } \\
\text { moderate numbers. Excision appeared complete. } \\
\text { Acute inflammation present elsewhere }\end{array}$ & Appendicectomy & $\begin{array}{l}\text { Alive and well } 1 \text { yr } \\
\text { later }\end{array}$ \\
\hline $\begin{array}{l}\text { Male } \\
38 \text { yr }\end{array}$ & Acute abdominal pain & $\begin{array}{l}\text { Appendix diffusely thickened by tumour. Goblet cells } \\
\text { and acini with occasional diazo positive cells and } \\
\text { Paneth cells. Invasion extended to serosal surface } \\
\text { and fat of mesoappendix }\end{array}$ & $\begin{array}{l}\text { Appendicectomy; } \\
\text { hemicolectomy } 1 \\
\text { mth later }\end{array}$ & $\begin{array}{l}\text { Alive and well } 6 \mathrm{mth} \\
\text { later. Residual } \\
\text { tumour present in } \\
\text { serosa of } \\
\text { hemicolectomy } \\
\text { specimen }\end{array}$ \\
\hline
\end{tabular}

Table III Carcinoid-like tumours with predominant mucoid element

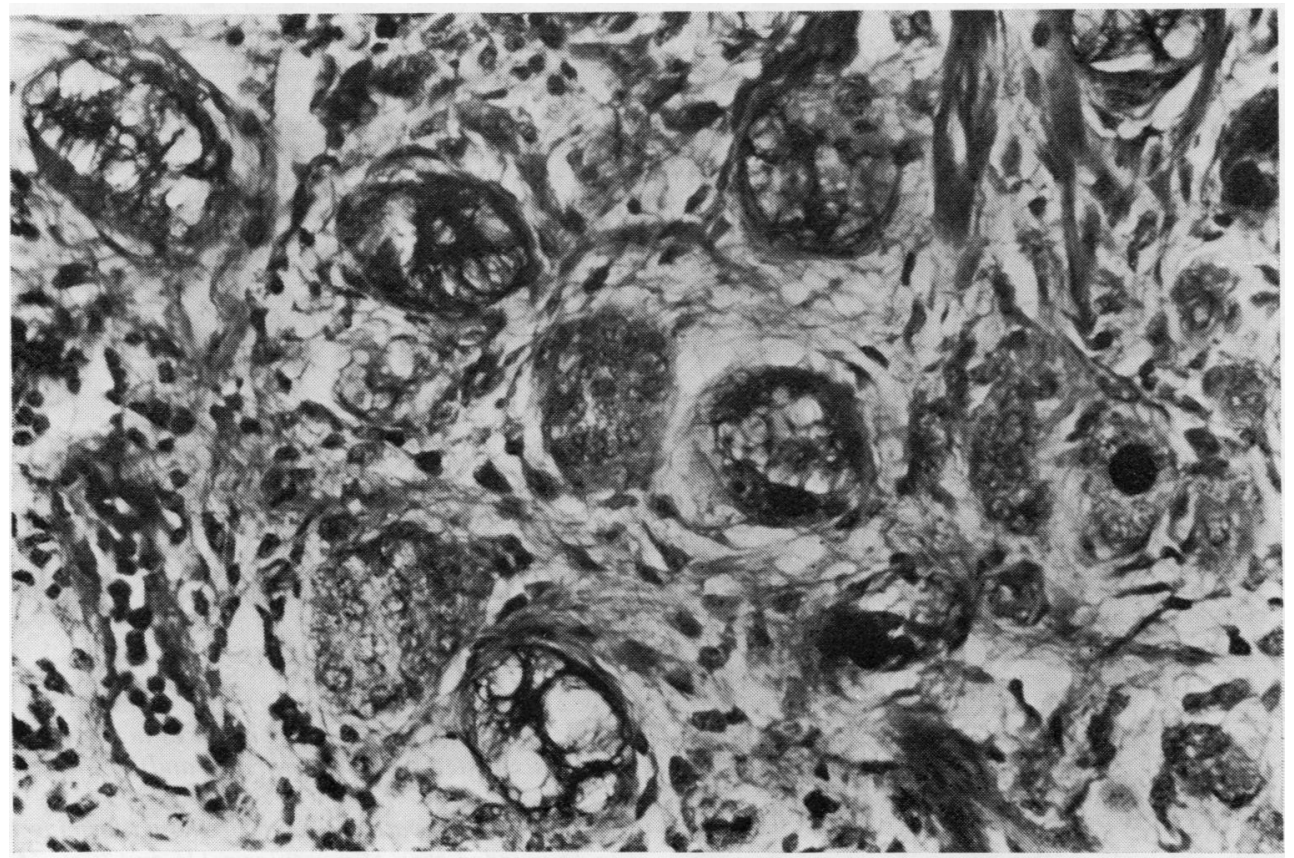

Fig 2 A mucinous carcinoid tumour with both solid diazo positive cords and acini containing darkly staining mucin. (Periodic acid Schiff $\times 315$ )

of carcinoids showing small numbers of mucinsecreting cells is comparable with that of other series (Dische, 1968; Soga and Tazawa, 1971).

In our series, 14 out of the 30 classical carcinoid tumours occurred at the tip, 12 in the middle third of the appendix, and three at the base; one involved almost the whole length of the organ. Most textbooks emphasize that the tip is the commonest site, but in this series only half of the carcinoids were at the tip and many of these were of microscopic dimensions and unassociated with abdominal pain (see table I). We feel that the emphasis on tumours at the tip may lead to tumours in other regions of the appendix being overlooked. Despite the fact that most of even the small carcinoids showed extensive invasion to the serosa and often into the mesoappendix, all were treated by simple appendicectomy and none has returned with recurrence or metastasis. The area has a stable population and any instances of recurrence would tend to return to the hospital group. This bears out the view that only in the very largest carcinoids is incomplete removal an indication for hemicolectomy.

The two cases in which diazo positive cells were equalled or outnumbered by mucin-secreting cells with an acinar and goblet-cell pattern correspond with tumours described by Subbuswamy et al (1974) as goblet-cell carcinoid, and by Klein (1974) as 


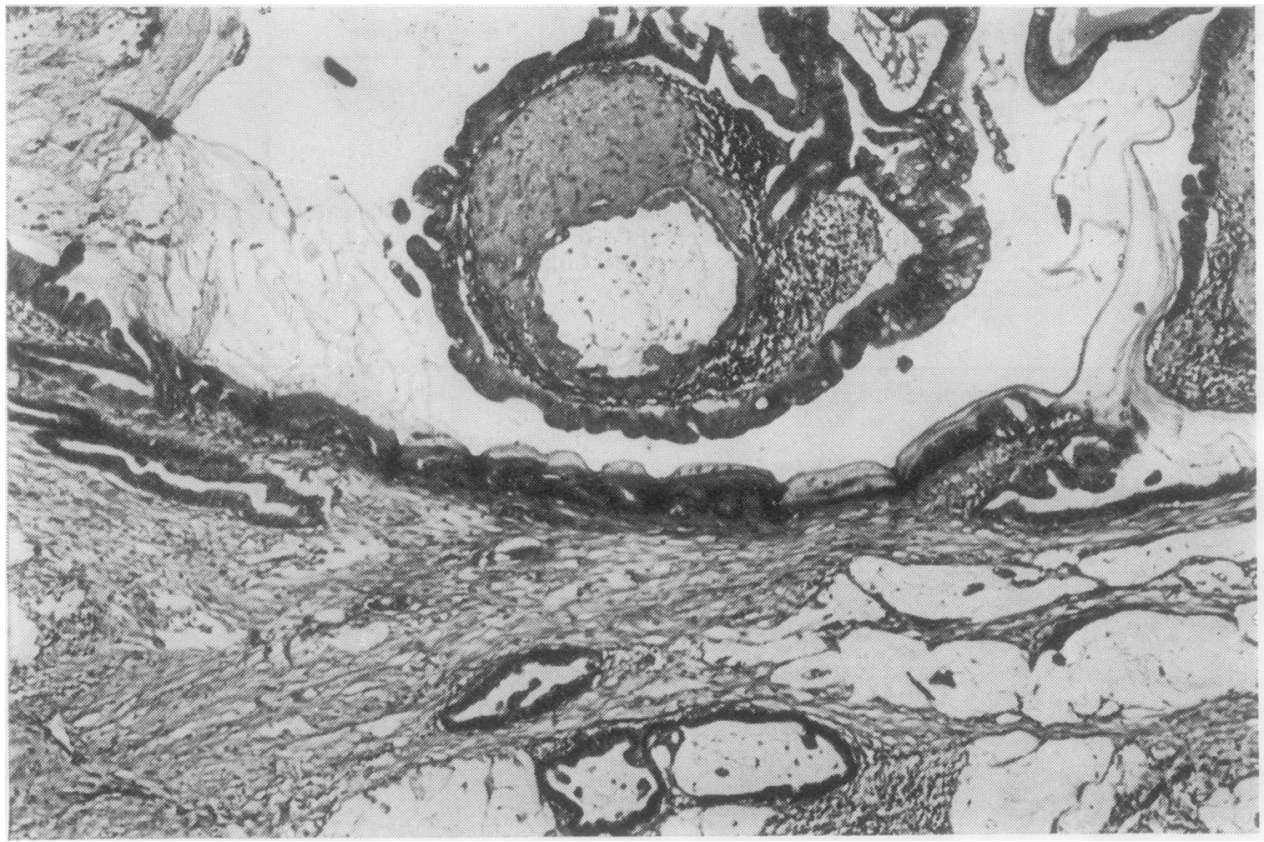

Fig 3

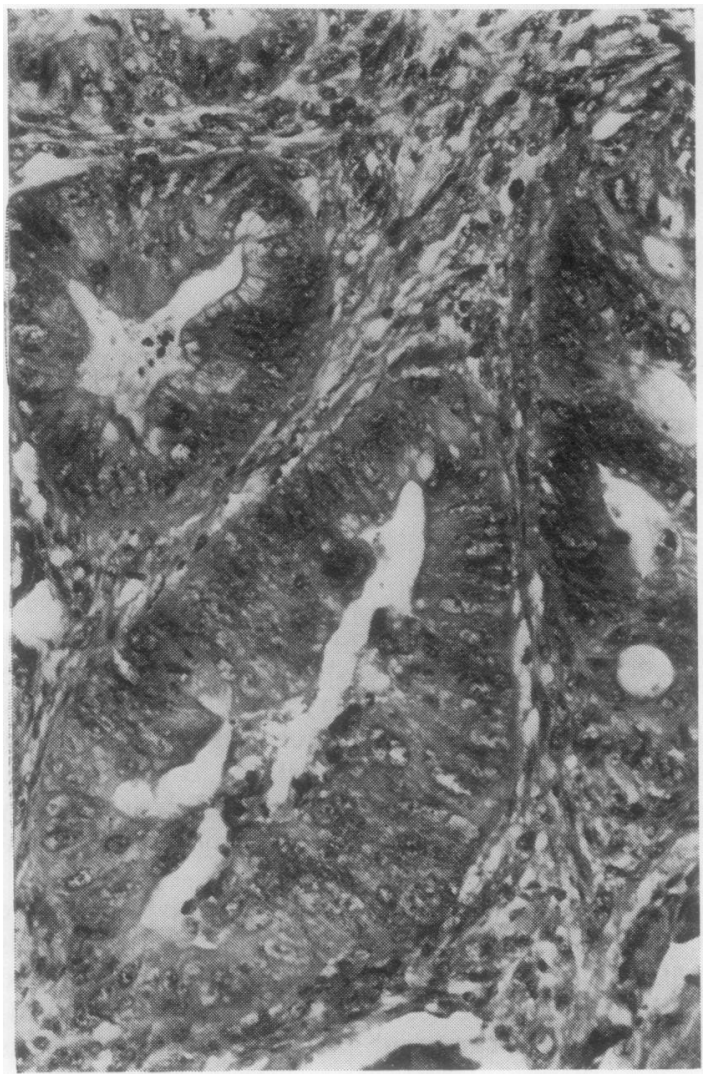

Fig 3 Mucoid cystadenocarcinoma invading the submucosa and forming mucous lakes in the wall of an appendix distended by tumour. ( $H$ and $E \times 50$ )

Fig 4 Colonic-pattern adenocarcinoma forming tubules in an invaded area of muscularis. ( $H$ and $E \times 247)$

Fig 4 


\begin{tabular}{|c|c|c|c|c|}
\hline Case & History & Pathology & Operation & Follow-up \\
\hline $\begin{array}{l}\text { Male } \\
70 \mathrm{yr}\end{array}$ & $\begin{array}{l}\text { Abdominal mass } \\
\text { palpated during an } \\
\text { admission for acute } \\
\text { retention }\end{array}$ & $\begin{array}{l}\text { Mucoid cystadenocarcinoma distending lumen of } \\
\text { appendix and invading serosa. Colon and other } \\
\text { viscera free of tumour but peritoneum covered by } \\
\text { small metastases (fig } 3 \text { ) }\end{array}$ & Colectomy & $\begin{array}{l}\text { Died } 1 \text { yr later, no } \\
\text { necropsy }\end{array}$ \\
\hline $\begin{array}{l}\text { Female } \\
76 \mathrm{yr}\end{array}$ & $\begin{array}{l}6 \text { mth abdominal } \\
\text { pain; } 24 \text { h guarding } \\
\text { and tenderness in } \\
\text { right iliac fossa }\end{array}$ & $\begin{array}{l}\text { Well-differentiated adenocarcinoma of colonic pattern } \\
\text { invading to the serosal surface. Appendix also } \\
\text { acutely inflamed (fig 4) }\end{array}$ & $\begin{array}{l}\text { Appendicectomy; } \\
\text { subsequent } \\
\text { laparotomy showed } \\
\text { multiple peritoneal } \\
\text { metastases }\end{array}$ & $\begin{array}{l}\text { Died } 2 \text { mth later. } \\
\text { Necropsy: multiple } \\
\text { peritoneal } \\
\text { metastases but no } \\
\text { primary tumour } \\
\text { elsewhere }\end{array}$ \\
\hline $\begin{array}{l}\text { Female } \\
84 \mathrm{yr}\end{array}$ & $\begin{array}{l}2 \text { mth spasmodic pain } \\
\text { in right iliac fossa } \\
\text { and intermittent } \\
\text { diarrhoea }\end{array}$ & $\begin{array}{l}\text { Mucoid cystadenocarcinoma distending appendix and } \\
\text { invading the wall. Colon and other viscera free of } \\
\text { tumour }\end{array}$ & Colectomy & $\begin{array}{l}\text { Alive and well } 9 \mathrm{mth} \\
\text { later }\end{array}$ \\
\hline $\begin{array}{l}\text { Male } \\
51 \mathrm{yr}\end{array}$ & Acute abdominal pain & $\begin{array}{l}\text { Well-differentiated tubular adenocarcinoma invading to } \\
\text { serosal surface. Appendix acutely inflamed and } \\
\text { perforated. Occasional diazo positive cells present in } \\
\text { tumour }\end{array}$ & $\begin{array}{l}\text { Appendicectomy; } \\
\text { hemicolectomy } \\
1 \mathrm{mth} \text { later }\end{array}$ & $\begin{array}{l}\text { Alive and well } 18 \\
\text { mth later. No } \\
\text { tumour in } \\
\text { hemicolectomy } \\
\text { specimen }\end{array}$ \\
\hline $\begin{array}{l}\text { Male } \\
61 \mathrm{yr}\end{array}$ & $\begin{array}{l}3 \text { days abdominal } \\
\text { pain, later developing } \\
\text { rebound tenderness } \\
\text { in right iliac fossa }\end{array}$ & $\begin{array}{l}\text { Gangrenous appendix with adenocarcinoma of } \\
\text { colonic pattern arising from mucosa close to base. } \\
\text { Colectomy specimen: tumour in caecal wall } \\
\text { adjacent to stump of appendix but no mucosal } \\
\text { tumour present in caecum }\end{array}$ & $\begin{array}{l}\text { Appendicectomy } \\
\text { and colectomy } 1 \mathrm{wk} \\
\text { later }\end{array}$ & $\begin{array}{l}\text { Alive and well } \\
18 \mathrm{mth} \text { later }\end{array}$ \\
\hline
\end{tabular}

Table IV Primary adenocarcinomas of the appendix

mucinous carcinoid tumour. Like the tumours described by these authors they also contain numbers of Paneth cells. In one of these cases the tumour invaded the serosal aspect of the resected colon as well. A further two cases of this condition occurred at this hospital outside the period under review, one of whom developed widespread peritoneal metastases after appendicectomy; the other died from myocardial infarction 18 months after appendicectomy and was free from tumour at necropsy. Our experience of this condition suggests that it is more aggressive in behaviour than the classical carcinoid tumour and that adequate histological examination of the excised appendix is necessary to assess completeness of excision and the need for further surgery.

The five cases of apparent primary adenocarcinoma of the appendix represent an incidence of $0.12 \%$ of appendicectomy specimens. This figure is unexpectedly high, but we feel that the findings at necropsy or at laparotomy and colectomy justify the view that these are true primary tumours of the appendix. Of the five tumours in this group, two are examples of the mucinous cystadenocarcinoma described by Higa et al (1973). The other three are adenocarcinomas of tubular structure resembling adenocarcinoma of the colon. In one of these colonic pattern adenocarcinomas, a small proportion of the tumour cells were diazo positive; this is also occasionally seen in primary adenocarcinomas of the stomach and colon.

A range of patterns is seen among primary appendiceal tumours, from carcinoids to welldifferentiated cystadenocarcinomas, through tumours containing varying proportions of enterochromaffin and mucin-producing cells. Traditionally, the two cell types have been held to arise from a common endodermal precursor, and neoplastic change in such a precursor could produce a tumour containing both types of cell. Pearse (1969) and Weichert (1970) have postulated a neural crest origin for cells of the enterochromaffin and APUD series. If the concept is accepted, tumours containing both mucinous and enterochromaffin cells could arise in two ways: first, by metaplasia of tumour cells of either neural crest or endodermal origin; secondly, by simultaneous neoplastic change in a field containing cells of both origins. Recent observations on lower animals may support the traditional view of a common precursor cell. Melmed et al (1972) confirm the existence of 'intermediate' cells in the pancreas of the goat, rat, and monkey. Such 'intermediate' cells have ultrastructural features of both exocrine mucin secretion and endocrine polypeptide secretion. If similar intermediate forms exist in the midgut and contain enterochromaffin granules, they could give rise to neoplasms containing both enterochromaffin and mucinous elements. Further studies of carcinoid and mucinous carcinoid tumours by electron microscopy would be needed to clarify this point.

All the secondary tumours, and three of the primary tumours, presented with symptoms of acute appendicitis and were macroscopically inflamed. Only on microscopy was it apparent that both acute appendicitis and malignant infiltration were present. In the other two primary tumours, the appendix was 
macroscopically infiltrated by tumour. In some laboratories it appears to be the practice to examine histologically only those appendices in which the operative findings are inconclusive (Gilmore $e t$ al, 1975). In our experience, the routine histological examination of all appendices has resulted in the discovery of a small number of potentially curable primary carcinomas of the appendix the presence of which was not apparent at operation.

The routine histopathological examination of appendicectomy specimens serves two purposes. If examination of the appendix at operation is inconclusive, histology may confirm or refute the diagnosis. In both inflamed and apparently normal appendices, histology may disclose additional pathology which may affect the subsequent clinical management of the patient. It is likely that in future the cost-effectiveness of many routine procedures may be more closely examined. We would submit that the additional findings on histological examination of the inflamed appendix may be of greater importance than those on the macroscopically normal or inconclusively inflamed appendix.

We wish to thank Professor I. M. P. Dawson and Dr A. Stevens for advice and encouragement and $\mathrm{Mr} \mathbf{W}$. Brackenbury for the photography. We would also like to thank the surgeons of the Mansfield Hospital Group for access to the clinical notes of these patients.

\section{References}

Collins, D. C. (1963). 71000 human appendix specimens. A final report, summarising forty years' study. Amer. J. Proctol., 14, 365-381.
Dische, F. E. (1968). Argentaffin and non-argentafinn carcinoid tumours of the appendix. J. clin. Path., 21, 6066.

Gilmore, O. J. A., Brodribb, A. J. M., Browett, J. P., Cooke $\frac{\bar{O}}{0}$ T. J. C., Griffin, P. H., Higgs, M. J., Ross, I. K., and Williamson, R. C. N. (1975). Appendicitis and mimicking $\frac{\overline{\bar{c}}}{\frac{\mathrm{S}}{7}}$
conditions. Lancet, 2, 421-424.

Grimelius, L. (1968). A silver nitrate stain for $a_{2}$ cells in human pancreatic islets. Acta Soc. Med. Upsalien, 73, 243270.

Higa, E., Rosai, J., Pizzimbono, C. A., and Wise, L. (1973). $\vec{\circ}$ Mucosal hyperplasia, mucinous cystadenoma, and. mucinous cystadenocarcinoma of the appendix. Cancer $\overrightarrow{\vec{\omega}}$ (Philad.), 32, 1525-1541.

Klein, H. Z. (1974). Mucinous carcinoid tumor of the vermi form appendix. Cancer (Philad.), 33, 770-777.

Latchis, K. S. and Canter, J. W. (1966). Acute appendicitisiu secondary to metastatic carcinoma. Amer. J. Surg., 111, 220-223.

Melmed, R. N., Benitez, C. J., and Holt, S. J. (1972). Inter-ळ mediate cells of the pancreas. I Ultrastructural characterization. J. Cell Sci., 11, 449-475.

Pearse, A. G. E. (1969). The cytoehemistry and ultrastructureof polypeptide-hormone producing cells of the APUDD series and the embryologic, physiologic and pathologic implications of the concept. J. Histochem. Cytochem., 17,

Singh, I. (1964). A modification of the Masson-Hamperl $\overrightarrow{0}$ method for staining of argentaffin cells. Anat. Anz., 115, 81 హె

Soga, J. and Tazawa, K. (1971). Pathologic analysis of carcinoids. Cancer (Philad.), 28, 990-998.

Solcia, E., Capella, C., and Vassallo, G. (1969). Lead haema toxylin as a stain for endocrine cells. Histochemie, 20, 116-⿳亠口冋 126.

Subbuswamy, S. G., Gibbs, N. M., Ross, C. F., and Morson, B. C. (1974). Goblet cell carcinoid of the appendix. Cancer (Philad.), 34, 338-344.

Weichert, R. F.III (1970). The neural ectodermal origin of the 3 peptide-secreting endocrine glands. A unifying concept for the etiology of multiple endocrine adenomatosis and the inappropriate secretion of peptide hormones by nonendocrine tumours. Amer. J. Med., 49, 232-241. 